\title{
The asthma epidemic and our artificial habitats
} Wasim Maziak*1,2

\author{
Address: ${ }^{1}$ Syrian Center for Tobacco Studies, Aleppo, Syria and ${ }^{2}$ Institute for Epidemiology and Social Medicine, University of Muenster, Germany \\ Email: Wasim Maziak* - maziak@net.sy \\ * Corresponding author
}

Published: 3I March 2005

BMC Pulmonary Medicine 2005, 5:5 doi:10.1 186/147I-2466-5-5

This article is available from: http://www.biomedcentral.com/I47I-2466/5/5

(C) 2005 Maziak; licensee BioMed Central Ltd.

This is an Open Access article distributed under the terms of the Creative Commons Attribution License (http://creativecommons.org/licenses/by/2.0), which permits unrestricted use, distribution, and reproduction in any medium, provided the original work is properly cited.
Received: 20 December 2004

Accepted: 31 March 2005

\begin{abstract}
Background: The recent increase in childhood asthma has been a puzzling one. Recent views focus on the role of infection in the education of the immune system of young children. However, this so called hygiene hypothesis fails to answer some important questions about the current trends in asthma or to account for environmental influences that bear little relation to infection.

Discussion: The multi-factorial nature of asthma, reflecting the different ways we tend to interact with our environment, mandates that we look at the asthma epidemic from a broader perspective. Seemingly modern affluent lifestyles are placing us increasingly in static, artificial, microenvironments very different from the conditions prevailed for most part of our evolution and shaped our organisms. Changes that occurred during the second half of the 20th century in industrialized nations with the spread of central heating/conditioning, building insulation, hygiene, TV/PC/games, manufactured food, indoor entertainment, cars, medical care, and sedentary lifestyles all seem to be depriving our children from the essential inputs needed to develop normal airway function (resistance). Asthma according to this view is a manifestation of our respiratory maladaptation to modern lifestyles, or in other words to our increasingly artificial habitats. The basis of the artificial habitat notion may lie in reduced exposure of innate immunity to a variety of environmental stimuli, infectious and non-infectious, leading to reduced formulation of regulatory cells/cytokines as well as inscribed regulatory pathways. This could contribute to a faulty checking mechanism of non-functional Th2 (and likely ThI) responses, resulting in asthma and other immuno-dysregulation disorders.
\end{abstract}

Summary: In this piece I discuss the artificial habitat concept, its correspondence with epidemiological data of asthma and allergy, and provide possible immunological underpinning for it from an evolutionary perspective of health and disease.

\section{Background}

Asthma is a major health problem that has reached alarming proportions in the past two decades in western societies [1]. What lies behind the recent increase in asthma in affluent societies is still an area of lively debate, but its rapid changing patterns and huge variation across populations favor environmental explanations [1-3]. While assessment of different old and new exposures is continuing, a unifying paradigm remains elusive, so as a guiding principle for prevention. The simultaneous increase of all forms of allergic disease on the other hand, argues for a change in host susceptibility/resistance [4]. 
The apparent association between asthma and western lifestyle has lead to numerous studies trying to link novel or increased exposures associated with westernizationmodernization, especially those occurring during childhood, to asthma. For example, exposure to gas cooking, tobacco smoke, trans fatty acids, domestic animals, and allergens were found to influence respiratory health, but did not provide a conclusive answer to the current trends in asthma [5-10]. While it is early to discard the role of these and other factors, a major contribution of asthma research during the past two decades lies in the elucidation of its heterogeneous and multi-factorial nature, where different exposures have different roles and relevance depending on the target population, setting, and disease course.

\section{Discussion I- The hygiene hypothesis and asthma}

Since its introduction in the nineties, the hygiene hypothesis $(\mathrm{HH})$ continues to generate enthusiasm among asthma researchers as the most comprehensive theoretical framework, by which the relation between suspected environmental factors and allergy can be tested [11-13]. This hypothesis originated from the coupling of observations on the allergy-protective effect of sibship size/birth-order with the emerging concept of helper T cell polarization into two counter-regulatory subsets; pro-infection Th1, and pro-allergy Th2 [14,15]. Backed by some experimental and clinical evidence [16-18], the hygiene hypothesis suggests that the recent rise in allergic disease among children in affluent societies is due the preferential programming of the $\mathrm{T}$ cell repertoire towards pro-allergy Th2 responses, brought by the decline in infections (increased hygiene, immunization, decreased sibship size, antibiotic use) [13-15]. With the increasing recognition of the role of $\mathrm{T}$ regulatory cells (Tregs) and cytokines in the pathogenesis of allergic inflammation, the hygiene paradigm has been extended recently integrating infection's role in generating such cells and mediators [19-21].

Asthma trends however, did not fit well with the hygiene model, which failed to explain the urban predominance of asthma, the increase in non-allergic asthma, the disparity between atopy and allergy in some populations, and the asthma inducing properties of some infections [2227]. Specifically, studies looking at the infection-asthma relationship failed to yield a consistent pattern so far [2834], prompting David Strachan, the father of the hygiene hypothesis, to conclude that "the totality of current evidence from cross sectional and longitudinal studies of common specific and non-specific infectious illnesses in infancy and childhood offers no support for the hygiene hypothesis" [11]. Other studies doubted even the fundamentals of the $\mathrm{HH}$ showing that the effect of siblings is not universal, or could have been programmed in utero rather than being a marker of childhood infection $[35,36]$. Perhaps the hygiene model's major shortcoming lies in its concentration on only one aspect (infection) of the drastic change that touched upon every detail of life in western societies in the past few decades. It also adopted a mechanistic approach for the study of adaptive immune responses and the relation between exposure-outcome, where an array of potential interactions are reduced to a single level; Th1-Th2 counter-regulation, siblings-infection, daycare attendance-infection, dog ownership-endotoxin, farming-endotoxin, etc. In brief, the search for a holy grail in the asthma epidemic may need to be replaced by the conceptualization of a more generalizing notion that allows for the consideration of multitude of factors within an ever changing environment.

\section{2- Asthma and our artificial habitats}

The hygiene model on the other hand, involved an evolutionary logic alerting us to the negative potential of sudden elimination of exposures that have shaped throughout the ages our organs and systems [37]. Health from such perspective is not about abstract assessment of the relation between exposure and outcome, or eliminating harmful exposures, but about seeing the whole dynamics of our interaction with our novel habitats [38]. Because of the slowness of adaptive evolutionary machinery, of particular interest according to this perspective are lifestyle factors that either witnessed a rapid change in recent times or represent an obvious departure from the conditions prevailed for most part of our evolution, i.e. factors likely to exemplify the discordance between our "Stone Age" genes and "Space Age" living conditions $[37,38]$.

General trends of asthma show that populations who conserved elements of ancient lifestyles have low levels of asthma. The north-south, urban rural, gradients in asthma occurrence have been extensively documented [24,37,3943]. In additions, studies in Africa show that some populations seem to be protected from asthma regardless of atopic predisposition or parasitic infection (both are Th2related) $[20,22,44-46]$. This indicates that some environmental influences associated with more traditional lifestyles are conferring respiratory resistance to stimuli that could have lead otherwise to clinically relevant airway inflammation. Within western societies furthermore, lower levels of asthma were found in families with traditional lifestyles $[47,48]$ and higher levels of asthma were found among obese or less physically fit children and adults [49-51]. Because not all these observations can be explained by variability in infection, or any other single factor for that matter, a broader concept seems more plausible. 
Modern life is increasingly placing us in static, artificial, micro-niches optimized for our convenience, but which bear little resemblance to the dynamic inputs provided by the environments that nurtured our evolution. In other words, we are increasingly living within an array of artificial habitats designed to handle us very well, but we may well not be equipped to handle them. Asthma according to this view, becomes a manifestation of our respiratory maladaptation to modern lifestyles. Changes that occurred during the second half of the $20^{\text {th }}$ century in industrialized countries with the spread of central heating/conditioning, building insulation, hygiene, TV/PC/ games, manufactured food, indoor entertainment, cars, medical care, and sedentary lifestyles all seem to be depriving our children from the essential inputs needed to develop normal airway function (resistance).

\section{3- Epidemiology of asthma from a new perspective}

The suggested view -called here the artificial habitat (AH)can provide alternative interpretations to existing data starting with the protective effect of sibship size/birthorder, which is one of the landmark observations of the $\mathrm{HH}$ that has been ascribed to increased exposure to infection [52]. It can be postulated that the mechanism of protection of siblings (especially older males) is related to their importance to the child's level of physical activity as well as ability to spend more time outdoors (i.e. in a more dynamic environment). This is particularly relevant to children living in dangerous neighborhoods, such as inner cities in the US, where the spread of asthma represents one of the main challenges to the hygiene paradigm [53]. Indeed, Andrew-Aligne and colleagues found that the higher prevalence of asthma among inner city black children is not due to race or low income per se, but to their living in an urban setting [54]. Additional intriguing support to the AH notion comes from the two largest studies looking at the effect siblings on the occurrence of allergy, whereby a stronger protective effect was observed for brothers than for sisters $[55,56]$. While exposure to infection cannot be expected to be related to sibling's gender, activity and outdoor time may well be influenced by this factor. By the same token, birth order can determine, among other things (e.g. social development, healthy food availability), the child's level of activity (how many playmates the child have) and ability to spent time outdoors. As new evidence are emerging against the HH's assumption considering the infection-related effect of the sibship size/birth-order, by showing for example that the role of birth order is independent of sibship size [57], and that in the same population sibship size can protect against asthma while infection predispose to it $[31,58]$, the AH concept seems to offer an alternative explanation.

Another important observation of the hygiene paradigm concerns the protective effect of early daycare attendance on later development of asthma, which is ascribed to increased exposure to infection [28]. Alternatively, it can be argued that the daily routine at a daycare center would be different in many aspects from home, in addition to exposure to infection. Reducing potential differences in activity, exposure, socio-behavioral development, and parental attitudes between those who do and don't attend daycare to mere infection seems over-simplistic. The AH concept looks at this observation from a broader angle involving a mixture of lifestyle and developmental factors. Related to this issue is the argued window of opportunity in early infancy for the protective effect of daycare attendance/infection $[59,60]$, which is connected to a critical period of immune education [13]. By its own nature in contrast, the $\mathrm{AH}$ view is consistent with the notion that environmental signals throughout the lifespan can affect the risk as well as the course of asthma and allergy.

On a different juncture of asthma research, a multitude of recently published reports show lower rates of asthma and atopy in children raised on a farm [61-68]. Heavily influenced by the $\mathrm{HH}$, these observations were largely attributed to increased exposure to bacterial components found in barns or farm milk (endotoxin in particular) [67-69], forgoing that children raised on a farm have very different lifestyles from children growing in inner cities in the US for example, where infection is also commonplace [70]. For example, one of the landmark farming studies has shown that endotoxin levels in children's mattresses were inversely associated with the occurrence of hay fever and atopic asthma [67]. However, leukocytes of children exposed to high levels of endotoxin produces less Th2 suppressing cytokines (mainly interleukin 10), arguing against the endotoxin-hygiene paradigm $[67,71,72]$. From the AH perspective however, a farm is the closest we can get in today's' western societies to conditions prevailed for most part of our evolution. Such an environment can provide ample opportunities of behaviors and exposures different from those of modern urban life.

The AH perspective is consistent with the assumption that time spent outdoors and level of physical activity should be protective against the development of asthma. A recent study by McConnell and colleagues however, has shown just the opposite, where the risk of developing asthma was positively associated with number of sports played and time spent outdoors [73] However, when participating communities were separated according to their level of atmospheric ozone, this association was only seen in the high ozone levels communities, while number of sports played and time spent outdoors seem to be protective in the low ozone communities [73]. On the other hand, twines in the Odense study who participated in conditioning exercise had a decreased risk of asthma compared to the more sedentary co-twins [51]. The physiological 
underpinning of the effect of activity on asthma can be partly elucidated by the work of Feldberg and colleagues and Togias and colleagues, who showed that disruption of dynamic breathing (static breathing without deep breaths or sighing) can lead to bronchial hyper-responsiveness (BHR), the pathophysiological hallmark of asthma $[74,75]$. Furthermore, recent evidence shows that obesity and weight gain are associated with increased risk of BHR [76], providing more insight on possible ways by which sedentary life factors can co-interact to predispose to asthma.

Finally, the AH concept can offer an explanation for some puzzling observations, such as the protective effect of dog ownership on asthma $[77,78]$. While the HH proponents looked for explanation in endotoxin levels associated with dog ownership, but with conflicting results so far [79], one can argue that the change in lifestyle (of children particularly) associated with dog ownership can be responsible (more playing, more time out, emotional interaction, as well as exposure to dog's constituents). Generally, families who opt to have a dog may be different from those who don't in being more active and outgoing. The focus here on activity and outdoor time is because these factors are clearly envisioned. Other aspects of traditional lifestyles may be just as important, such as household air exchange (e.g. affecting allergens, pollutants, humidity), nutritional habits (e.g. breast feeding), as well behavioral adaptations.

\section{4- An innate control of asthma and allergy}

Now how can the AH view be related to what we know about the immunopathology of asthma and allergy? Asthma is an immunological disorder with a predominant Th2 inflammatory response in the airways. This Th2 response is thought to be a remnant of our ability to expel parasites abundant in the cradle of human evolution, the tropical savannah [80]. Indeed, evidence exist showing that Th2 pro-inflammatory genetic alleles are more prevalent in populations with a tropical origin than those with a temperate one [81]. It is possible that the need to deal with a wide variety of pathogens may have meant that the activation threshold of Th2 responses has to be set low, leading to many false alarms to non-pathogenic particles and giving rise to asthma. Evolutionary logic indicates however, that a trait with a potential to endanger air passage into our vital respiratory organs would not have been selected, had some regulatory mechanisms not been in place. Studies on the initial phase of allergic sensitization show that a transient low-level IgE (the atopic antibody) response to inhalant antigen occurs in normal children, with those who do not develop allergy down-regulate it in the first years of life [82-84]. Asthma in this regard, becomes a manifestation of breakdown of regulatory mechanisms at respiratory mucosal surfaces.
But let's take one step back to look at another recent puzzling trend; the increase of Th1 autoimmune disorders such as type-1 diabetes and multiple sclerosis in western societies [21]. Recent evidence suggests that that the two groups (Th1 and Th2 mediated diseases) can be associated in individuals [85-88], arguing against the Th1-Th2 counter-suppression of the $\mathrm{HH}$, and favoring a common ground of faulty regulation. Such developments were picked up by proponents of the $\mathrm{HH}$ to suggest that hygiene can work through depriving the immune system from signals necessary for the development of regulatory pathways/cells capable of dampening both Th1 and Th2 responses $[89,90]$. While this can be true, the focus on infection yet again is a reductionistic view likely to suffer the same shortcomings of the original Th1-Th2 counterregulation of the $\mathrm{HH}$. At the same time, advances made in immunology were unraveling the central role of the innate immune system in orchestrating immune responses [91]. In particular, antigen presenting cells, such as dentritic cells (DCs), can engage infectious components with their Toll-like receptors (TLRs) (a group of ancient immune recognition molecules) leading to activation of adaptive immune responses and induction of regulatory cells and mediators [92,93]. In their turn, T regulatory cells (Tregs), which are induced naturally or by elements of innate immunity are able to regulate all types of adaptive immune responses as well as influence DCs activation and regulation [94,95]. Interestingly, it looks that none of the Th1, Th2, or Treg-inducing functions of DCs is an intrinsic attribute that is not sensitive to instructions from the surrounding environment [96,97]. Without getting into the details of this fascinating and still unfolding field, the move from the see/saw mechanistic counter-regulation of adaptive Th1-Th2 responses to elements of innate immunity offers an evolutionary sound and possibly robust checking mechanism (break) against inappropriate responses (e.g. Th2 responses to non-pathogenic elements) at our vital airways. The ability of DCs to be activated in response to danger signals induced by stress, damage, or necrotic cell death [98], and the role of DCs at the gastrointestinal tract in the development of mucosal tolerance [99], broadens their possible range of involvement with different environmental stimuli and thus their contribution to immune homeostasis at the respiratory surface. For example, heat-shock proteins (hsps, which are highly conserved cellular proteins that can be produced by thermal stimuli, physical activity, or other stresses) can activate DCs as well as contribute to T cell regulation of inflammatory responses [100,101].

Taken together, it can be suggested according to the $\mathrm{AH}$ concept that dynamic/traditional lifestyles with associated exposures can ensure constant challenge of DCs and other elements of innate immunity giving rise to immune responses, but at the same time maintaining adequate 
turnover of regulatory cells and cytokines and inscribed regulatory pathways. This ongoing activation of regulatory pathways can help maintain healthy control of nonfunctional Th2 responses at the respiratory surface. The DC-orchestrated dynamic balance between Th2 responses and regulatory mechanisms is likely to influence all phases (initiation, effector) of inflammation in the airways, and throughout the lifespan of the individual.

\section{Summary}

While it offers no specific explanation to different asthma trends and variations, the suggested $\mathrm{AH}$ notion provides a generalizing scheme for the study of asthma, and provides novel insights for existing epidemiological observations. According to this perspective there is no single answer to the asthma epidemic, but different factors have different relevance depending on the population and environment in focus. In addition to being free from the $\mathrm{HH}$ onedimensional approach for the relation between exposureoutcome, this view is evolutionary-driven allowing to place the asthma epidemic within the wider perspective of increasing discordance between us and our dramatically changing environments. Sedentary lifestyles, static indoor microenvironments, and automation of the food chain are apparently not only predisposing us to obesity ad cardiovascular disease but also depriving our respiratory system from many stimuli necessary for the development of normal airway resistance. The immunological basis of the AH notion can lie in the centrality of innate immunity and its ability to respond to different types of environmental stimuli, insuring adequate turnover of regulatory cells and mediators. The evolutionary tenet "the more we change the world the more we stay the same" probably lacks accuracy. Newer environments, constantly confront us with new adaptive challenges that should be looked upon, as in the case of asthma, within the evolutionary context of health and disease.

\section{Abbreviations}

HH- hygiene hypothesis

AH- artificial habitat

DCs- dentritic cells

BHR- bronchial hyper-responsiveness

IL10- interleukin 10

hsps- heat shock proteins

Th1- T helper cell type 1

Th2- T helper cell type 2
Tregs- regulatory T cells

IgE- immunoglobuline $\mathrm{E}$

TLRs- Toll-like receptors

\section{Competing interests}

The author(s) declare that they have no competing interests.

\section{Authors' contributions}

Dr. Wasim Maziak is the sole author and contributor to this manuscript.

\section{Acknowledgements}

Dr. Wasim Maziak is supported by USPHS grants R0I TW05962 and R2I TW006545.

\section{References}

I. Kay AB: Allergy and allergic diseases. First of two parts. N Engl $J$ Med 200I, 344(I):30-37.

2. Kay AB: Allergy and allergic diseases. Second of two parts. $N$ Engl J Med 200 I, 344(2): 109-1 I3.

3. von Mutius $\mathrm{E}$ : The environmental predictors of allergic disease. J Allergy Clin Immunol 2000, 105:9-19.

4. Strachan DP: Time trends in asthma and allergy: ten questions, fewer answers. Clin Exp Allergy 1995, 25(9):79|-4.

5. Belanger K, Beckett W, Triche E, Bracken MB, Holford T, Ren P, McSharry JE, Gold DR, Platts-Mills TA, Leaderer BP: Symptoms of wheeze and persistent cough in the first year of life: associations with indoor allergens, air contaminants, and maternal history of asthma. Am J Epidemiol 2003, I, I 58(3): 195-202.

6. Janson C: The effect of passive smoking on respiratory health in children and adults. Int J Tuberc Lung Dis 2004, 8(5):5 I0-6.

7. Weiland SK, von Mutius E, Husing A, Asher MI: Intake of trans fatty acids and prevalence of childhood asthma and allergies in Europe. ISAAC Steering Committee. Lancet 1999, 353(9169):2040-I.

8. Lanphear BP, Aligne CA, Auinger P, Weitzman M, Byrd RS: Residential exposures associated with asthma in us children. Pediatrics 200I, I07(3):505-II.

9. Sporik R, Platts-Mills TA: Allergen exposure and the development of asthma. Thorax 200I, 56(Suppl 2):ii58-63.

10. Wright AL: The epidemiology of the atopic child: who is at risk for what? J Allergy Clin Immunol 2004, I I 3(I Suppl):S2-7.

II. Strachan DP: Family size, infection and atopy: the first decade of the "hygiene hypothesis". Thorax 2000, 55(Suppl I):2-I0.

12. Martinez FD: The coming-of-age of the hygiene hypothesis. Respir Res 2001, 2(3): 129-32.

13. Martinez FD, Holt PG: Role of microbial burden in aetiology of allergy and asthma. Lancet 1999, 354(suppI II): I2I5-2I.

14. Strachan DP: Hay fever, hygiene, and household size. BMJ 1989 , 299: $1259-60$.

15. Cookson WO, Moffatt MF: Asthma: an epidemic in the absence of infection? Science 1997, 275(5296):4|-2.

16. Kline JN, Waldschmidt TJ, Businga TR, Lemish JE, Weinstock JV, Thorne PS, Krieg AM: Cutting edge: modulation of airway inflammation by CpG oligodeoxynucleotides in a murine model of asthma. J Immunol 1998, I 60(6):2555-2559.

17. Gereda JE, Leung DY, Thatayatikom A, Streib JE, Price MR, Klinnert MD, Liu AH: Relation between house-dust endotoxin exposure, type I T-cell development, and allergen sensitisation in infants at high risk of asthma. Lancet 2000, 355(92 |6): 1680-1683.

18. Kalliomaki M, Salminen S, Arvilommi H, Kero P, Koskinen P, Isolauri $\mathrm{E}$ : Probiotics in primary prevention of atopic disease: a randomised placebo-controlled trial. Lancet 200I, 357(9262): 1076-9. 
19. Romagnani S: The increased prevalence of allergy and the hygien hypothesis: missing immune deviation, reduced immune suppression, or both? Immunology 2004, I I 2:352-363.

20. Yazdanbakhsh M, Kremsner PG, van Ree R: Allergy, parasites, and the hygiene hypothesis. Science 2002, 296(5567):490-4.

21. Bach JF: The effect of infections on susceptibility to autoimmune and allergic diseases. $N$ Engl J Med 2002, 347( I 2):9| I-20.

22. Yemaneberhan H, Bekele Z, Venn A, Lewis S, Parry E, Britton J: Prevalence of wheeze and asthma and relation to atopy in urban and rural Ethiopia. Lancet 1997, 350:85-90.

23. Litonjua AA, Carey VJ, Weiss ST, Gold DR: Race, socioeconomic factors, and area of residence are associated with asthma prevalence. Pediatr Pulmonol 1999, 28:394-40I.

24. Kuehni CE, Davis A, Brooke AM, Silverman M: Are all wheezing disorders in very young (preschool) children increasing in prevalence? Lancet 200I, 357(927I): $1821-5$.

25. Leung R, Ho P: Asthma, allergy, and atopy in three south-east Asian populations. Thorax 1994, 49( I 2): 1205-10.

26. Umetsu DT: Flu strikes the hygiene hypothesis. Nat Med 2004, I0(3):232-4

27. Maziak W: The ThI-Th2 paradigm and asthma; how far should we go? Asthma 2003, 40:201-205.

28. Ball TM, Castro-Rodriguez JA, Griffith KA, Holberg CJ, Martinez FD, Wright AL: Sibling, day-care attendance, and the risk of asthma and wheezing during childhood. N Eng J Med 2000, 343(8):538-43.

29. Nystad W, Skrondal A, Magnus P: Day care attendance, recurrent respiratory tract infections and asthma. Int I Epidemiol 1999, 28(5):882-887.

30. Illi S, von Mutius E, Lau S, Bergmann R, Niggemann B, Sommerfeld C, Wahn U: Early childhood infectious diseases and the development of asthma up to school age: a birth cohort study. $B M$ J 200I, 322(7283):390-395.

31. Nafstad P, Magnus $P$, Jaakkola J]: Early respiratory infections and childhood asthma. Pediatrics 2000, $106(3)$ :E38.

32. Castro-Rodriguez JA, Holberg CJ, Morgan WJ, Wright AL, Halonen $M$, Taussig LM, Martinez FD: Relation of two different subtypes of croup before age three to wheezing, atopy, and pulmonary function during childhood: a prospective study. Pediatrics 200I, 107(3):5I2-5I8.

33. Cardoso MR, Cousens SN, de Goes Siqueira LF, Alves FM, D'Angelo LA: Crowding: risk factor or protective factor for lower respiratory disease in young children? BMC Public Health 2004, 4(1): 19 .

34. Kramer MS, Guo T, Platt RW, Sevkovskaya Z, Dzikovich I, Collet JP, Shapiro S, Chalmers B, Hodnett E, Vanilovich I, Mezen I, Ducruet T, Shishko G, Bogdanovich N: Does previous infection protect against atopic eczema and recurrent wheeze in infancy? Clin Exp Allergy 2004, 34(5):753-6.

35. Van Gool C], Thijs C, Dagnelie PC, Henquet CJ, van Houwelingen AC, Schrander J, Menheere PP, van den Brandt PA: Determinants of neonatal IgE level: parity, maternal age, birth season and perinatal essential fatty acid status in infants of atopic mothers. Allergy 2004, 59(9):96I-8.

36. Karmaus W, Botezan C: Does a higher number of siblings protect against the development of allergy and asthma? A review. J Epidemiol Community Health 2002, 56(3):209-17.

37. Maziak W: Asthma and the exposure-disease tenet. $j$ Clin Epidemiol 2002, 55(8):737-40.

38. Maziak $W$ : The hygiene hypothesis and the evolutionary perspective of health. Prev Med 2002, 35(4):4I5-8.

39. Weinberg EG: Urbanization and childhood asthma: an African perspective. J Allergy Clin Immunol 2000, 105(2 Pt I):224-3I.

40. Hijazi N, Abalkhail B, Seaton A: Asthma and respiratory symptoms in urban and rural Saudi Arabia. Eur Respir J 1998, I 2:4 I-4.

41. AddoYobo EO, Custovic A, Taggart SC, Asafo-Agyei AP, Woodcock $A$ : Exercise induced bronchospasm in Ghana: differences in prevalence between urban and rural schoolchildren. Thorax 1997, 52(2): $161-5$

42. Zhao Tb, Wang A, Chen Y, Xiao M, Duo L, Liu G, Lau Y, Karlberg J: Prevalence of childhood asthma, allergic rhinitis and eczema in Urumqi and Beijing. J Paediatr Child Health 2000, 36(2): I28-33.

43. The International Study of Asthma and Allergies in Childhood (ISAAC) Steering Committee: Worldwide variation in prevalence of symptoms of asthma, allergic rhinoconjunctivitis, and atopic eczema: ISAAC. Lancet I998, 35 I(9 I I I): I225-32.
44. Walraven GE, Nyan OA, Van Der Sande MA, Banya WA, Ceesay SM, Milligan PJ, McAdam KP: Asthma, smoking and chronic cough in rural and urban adult communities in The Gambia. Clin Exp Allergy 200I, 3 I (I I): I679-85.

45. Van den Biggelaar AH, van Ree R, Rodrigues LC, Lell B, Deelder AM, Kremsner PG, Yazdanbakhsh M: Role for parasite-induced interluekine- 10 in children infected by Schistosoma haematobium. Lancet 2000, 356:1723-27.

46. Nyan OA, Walraven GE, Banya WA, Milligan P, Van Der Sande M, Ceesay SM, Del Prete G, McAdam KP: Atopy, intestinal helminth infection and total serum IgE in rural and urban adult Gambian communities. Clin Exp Allergy 200I, 3 I(II):1672-8.

47. Alm J, Swartz J, Lilja G, Scheynius A, Pershagen G: Atopy in children of families with an anthroposophic lifestyle. Lancet 1999 353:1485-88.

48. Kearney PM, Kearney PJ: The prevalence of asthma in schoolboys of travellers' families. Ir Med J 1998, 9 I(6):203-6.

49. Oddy WH, Sherriff JL, de Klerk NH, Kendall GE, Sly PD, Beilin LJ, Blake KB, Landau LI, Stanley FJ: The relation of breastfeeding and body mass index to asthma and atopy in children: a prospective cohort study to age 6 years. Am J Public Health 2004, 94(9): $153 \mid-7$

50. Nystad W, Meyer HE, Nafstad P, Tverdal A, Engeland A: Body mass index in relation to adult asthma among 135,000 Norwegian men and women. Am J Epidemiol 2004, 160 (10):969-76.

51. Rasmussen F, Lambrechtsen J, Siersted HC, Hansen HS, Hansen NC: Low physical fitness in childhood is associated with the development of asthma in young adulthood: the Odense schoolchild study. Eur Respir J 2000, I 6(5):866-70.

52. Strachan DP: Allergy and family size: a riddle worth solving. Clin Exp Allergy 1997, 27(3):235-6.

53. Matricardi PM, Bouygue GR, Tripodi S: Inner-city asthma and the hygiene hypothesis. Ann Allergy Asthma Immunol 2002, 89(6 Suppl I):69-74.

54. Andrew Aligne C, Auinger P, Byrd RS, Weitzman M: Risk factors for pediatric asthma. Contributions of poverty, race, and urban residence. Am J Respir Crit Care Med 2000, $162(3$ Pt I):873-7.

55. Svanes C, Jarvis D, Chinn S, Burney P: Childhood environment and adult atopy: results from the European Community Respiratory Health Survey. J Allergy Clin Immunol I999, 103:4I 5-20.

56. Strachan DP, Harkins LS, Golding J: Sibship size and self-reported inhalant allergy among adult women. Clin Exp Allergy 1997, 27:|15I-55.

57. Bernsen RM, de Jongste JC, van der Wouden JC: Birth order and sibship size as independent risk factors for asthma, allergy, and eczema. Pediatr Allergy Immunol 2003, I 4(6):464-9.

58. Bodner C, Godden D, Seaton A: Family size, childhood infections and atopic diseases. The Aberdeen WHEASE Group. Thorax 1998, 53(I):28-32.

59. Kramer U, Heinrich J, Wjst M, Wichmann HE: Age of entry to day nursery and allergy in later childhood. Lancet 353(9 I 5 I):450-4. 1999 Feb 6

60. Riedler J, Braun-Fahrlander C, Eder W, Schreuer M, Waser M, Maisch S, Carr D, Schierl R, Nowak D, von Mutius E: ALEX Study Team. Exposure to farming in early life and development of asthma and allergy: a cross-sectional survey. Lancet 200I, 358(9288): I I 29-33

61. Braun-Fahrlander C, Gassner M, Grize L, Neu U, Sennhauser FH, Varonier HS, Vuille JC, Wuthrich B: Prevalence of hay fever and allergic sensitization in farmer's children and their peers living in the same rural community. SCARPOL team. Swiss Study on Childhood Allergy and Respiratory Symptoms with respect to air pollution. Clin Exp Allergy 1999, 29(I):28-34.

62. Riedler J, Eder W, Oberfeld G, Schreuer M: Austrian children living on a farm have less hey fever, asthma and allergic sensitization. Clin Exp Allergy 2000, 30(2): 194-200.

63. Kilpelainen $\mathrm{M}$, Terho $\mathrm{EO}$, Helenius $\mathrm{H}$, Koskenvuo M. Farm environment in childhood prevents the development of allergy. Clin Exp Allergy 2000, 30(2):201-8.

64. Ernst P, Cormier Y: Relative scarcity of asthma and atopy among rural adolescents raised on a farm. Am J Respir Crit Care Med 2000, I6I(5): I563-6.

65. Von Ehrenstein OS, von Mutius E, Illi S, Baumann L, Bohm O, von Kries R: Reduced risk of hay fever and asthma among children of farmers. Clin Exp Allergy 2000, 30(2): 187-93. 
66. Braback L, Hjern A, Rasmussen F: Trends in asthma, allergic rhinitis and eczema among Swedish conscripts from farming and non-farming environments. A nationwide study over three decades. Clin Exp Allergy 2004, 34(I):38-43.

67. Braun-Fahrlander C, Riedler J, Herz U, Eder W, Waser M, Grize L, Maisch S, Carr D, Gerlach F, Bufe A, Lauener RP, Schierl R, Renz H, Nowak D, von Mutius E, Allergy and Endotoxin Study Team: Environmental exposure to endotoxin and its relation to asthma in school-age children. N Engl J Med 2002, 347( I 2):869-77.

68. Riedler J, Braun-Fahrlander C, Eder W, Schreuer M, Waser M, Maisch S, Carr D, Schierl R, Nowak D, von Mutius E: Exposure to farming in early life and development of asthma and allergy: a crosssectional survey. Lancet 200 I, 358(9288): I I29-33.

69. Von Mutius E, Braun-Fahrlander C, Schierl R, Riedler J, Ehlermann S, Maisch S, Waser M, Nowak D: Exposure to endotoxin or other bacterial components might protect against the development of atopy. Clin Exp Allergy 2000, 30(9): I 230-1234.

70. Maziak W: Asthma and farming. Lancet 2002, 359(9306):623.

7I. Holla AD, Roy SR, Liu AH: Endotoxin, atopy and asthma. Curr Opin Allergy Clin Immunol 2002, 2(2): I4|-5.

72. Maziak W: Endotoxin and Asthma. New Eng J Med 2003 348: $17 \mid-72$

73. McConnell R, Berhane K, Gilliland F, London SJ, Islam T, Gauderman WJ, Avol E, Margolis HG, Peters JM: Asthma in exercising children exposed to ozone: a cohort study. Lancet 2002, 359(9304):386-91.

74. Fredberg JJ, Inouye DS, Mijailovich SM, Butler JP: Perturbed equilibrium of myosin binding in airway smooth muscle and its implications in bronchospasm. Am J Respir Crit Care Med 1999. 159:959-67.

75. Kapsali T, Permutt S, Laube B, Scichilone N, Togias A: The potent bronchoprotective effect of deep inspiration and its absence in asthma. J Appl Physiol 2000, 89:7II-720.

76. Litoniua AA, Sparrow D, Celedon JC, DeMolles D, Weiss ST: Association of body mass index with the development of methacholine airway hyperresponsiveness in men: the Normative aging Study. Thorax 2002, 57(7):58I-5.

77. Litonjua AA, Milton DK, Celedon JC, Ryan L, Weiss ST, Gold DR: A longitudinal analysis of wheezing in young children: the independent effects of early life exposure to house dust endotoxin, allergens, and pets. J Allergy Clin Immunol 2002, I I 0(5):736-42.

78. Remes ST, Castro-Rodriguez JA, Holberg CJ, Martinez FD, Wright $\mathrm{AL}$ : Dog exposure in infancy decreases the subsequent risk of frequent wheeze but not of atopy. I Allergy Clin Immunol 200I, 108(4):509-15.

79. Simpson A, Custovic A: Early pet exposure: friend or foe? Curr Opin Allergy Clin Immunol 2003, 3(I):7-14.

80. Pritchard DI, Hewitt C, Moqbel R: The relationship between immunological responsiveness controlled by T-helper lymphocytes and infections with parasitic helminths. Parasitology 1997, II 5:S33-S44.

8I. Le Souef PN, Goldblatt J, Lynch NR: Evolutionary adaptation of inflammatory immune responses in human beings. Lancet 2000, 356:242-244.

82. Hattevig G, Kjellman B, Bjorksten B: Appearance of IgE antibodies to ingested and inhaled allergens during the first $I 2$ years of life in atopic and non-atopic children. Pediatr Allergy Immunol $1993,4(4): 182-6$.

83. Holt PG, O'Keeffe P, Holt BJ, Upham JW, Baron-Hay MJ, Suphioglu C, Knox B, Stewart GA, Thomas WR, Sly PD: T-cell "priming" against environmental allergens in human neonates: sequential deletion of food antigen reactivity during infancy with concomitant expansion of responses to ubiquitous inhalant allergens. Pediatr Allergy Immunol 1995, 6(2):85-90.

84. Halstensen TS: Why are we not all allergic: basic mechanisms for tolerance development. Environ Toxicol Pharmacol 1997, 4:25-31.

85. Patterson CC, Dahlquist G, Soltesz G, Green A: The EURODIAB ACE Study Group. Europe and Diabetes. Is childhood-onset type I diabetes a wealth-related disease? An ecological analysis of European incidence rates. Diabetologia 200I, 44(Suppl 3):B9-16.

86. Poser S, Stickel B, Krtsch U, Burckhardt D, Nordman B: Increasing incidence of multiple sclerosis in South Lower Saxony, Germany. Neuroepidemiology 1989, 8(4):207-I3.
87. Kero J, Gissler M, Hemminki E, Isolauri E: Could THI and TH2 diseases coexist? Evaluation of asthma incidence in children with coeliac disease, type I diabetes, or rheumatoid arthritis: a register study. J Allergy Clin Immunol 200I, 108(5):78I-3.

88. Simpson CR, Anderson WJ, Helms PJ, Taylor MW, Watson L, Prescott G], Godden DJ, Barker RN: Coincidence of immune-mediated diseases driven by ThI and Th2 subsets suggests a common aetiology. A population-based study using computerized general practice data. Clin Exp Allergy 2002, 32(I):37-42

89. Wills-Karp M, Santeliz J, Karp CL: The germless theory of allergic disease: revisiting the hygiene hypothesis. Nat Rev Immunol 200I, I(I):69-75.

90. Braun-Fahrlander C: Environmental exposure to endotoxin and other microbial products and the decreased risk of childhood atopy: evaluating developments since April 2002. Curr Opin Allergy Clin Immunol 2003, 3(5):325-9.

91. Medzhitov R, Janeway C Jr: Innate immunity. N Eng J Med 2000 343(5):338-44

92. Kuipers $\mathrm{H}$, Lambrecht $\mathrm{BN}$ : The interplay of dendritic cells, Th2 cells and regulatory T cells in asthma. Curr Opin Immunol 2004 16(6):702-8.

93. Hayashi T, Beck L, Rossetto C, Gong X, Takikawa O, Takabayashi K, Broide DH, Carson DA, Raz E: Inhibition of experimental asthma by indoleamine 2,3-dioxygenase. J Clin Invest 2004, I I 4(2):270-9.

94. Robinson DS, Larche M, Durham SR: Tregs and allergic disease. Clin Invest 2004, I I 4( I 0): 1389-97.

95. Mason $D$, Powrie $F$ : Control of immune pathology by regulatory T cells. Curr Opin Immunol 1998, I0(6):649-55.

96. Weiner $\mathrm{HL}$ : The mucosal milieu creates tolerogenic dendritic cells and $\mathbf{T}(\mathbf{R}) \mathbf{I}$ and $\mathbf{T}(\mathbf{H}) \mathbf{3}$ regulatory cells. Nat Immunol 200I, 2(8):67I-2.

97. Vieira PL, de Jong EC, Wierenga EA, Kapsenberg ML, Kalinski $P$ Development of ThI-inducing capacity in myeloid dendritic cells requires environmental instruction. Immunology 2000, I64(9):4507-I2.

98. Gallucci S, Matzinger P: Danger signals: SOS to the immune system. Curr Opin Immunol 200 I, I 3(I): I I 4-9.

99. Noverr MC, Huffnagle GB: Does the microbiota regulate immune responses outside the gut? Trends Microbiol 2004 12(12):562-8

100. Singh-Jasuja H, Scherer HU, Hilf N, Arnold-Schild D, Rammensee HG, Toes RE, Schild $\mathrm{H}$ : The heat shock protein gp96 induces maturation of dendritic cells and down-regulation of its receptor. Eur J Immunol 2000, 30( I 8):22III-22I5.

10I. Van Eden W, van der Zee R, Paul AG, Prakken BJ, Wendling U, Anderton SM, Wauben MH: Do heat shock proteins control the balance of $\mathrm{T}$-cell regulation in inflammatory diseases? Immunol Today 1998, 19(7):303-7.

\section{Pre-publication history}

The pre-publication history for this paper can be accessed here:

\section{http://www.biomedcentral.com/1471-2466/5/5/prepub}

Publish with BioMed Central and every scientist can read your work free of charge

"BioMed Central will be the most significant development for disseminating the results of biomedical research in our lifetime. "

Sir Paul Nurse, Cancer Research UK

Your research papers will be:

- available free of charge to the entire biomedical community

- peer reviewed and published immediately upon acceptance

- cited in PubMed and archived on PubMed Central

- yours - you keep the copyright

Submit your manuscript here:

http://www.biomedcentral.com/info/publishing_adv.asp
BioMedcentral 